$\xi=-1$

\title{
Factors Influencing the Success of Teaching of Universitas Pgri Semarang Students in International PPL Program in Malaysia
}

\author{
Muhdi $^{* 1}$, Suwarno Widodo ${ }^{2}$, Achmad Buchori ${ }^{3}$, Ririn Ambarini ${ }^{4}$ Nur Fadhila $^{5}$ \\ ${ }^{1,2,3,4}$ Lecturer Universitas PGRI Semarang, Central Java, Indonesia \\ ${ }^{5}$ Lecturer Education Programe, Universiti Teknologi Malaysia \\ *Corresponding authorEmail:Muhdi@upgris.ac.id,achmadbuchori@upgris.ac.id,suwarnowidodo@upgris,ac.id , \\ ririnambarini@upgris.ac.id,p-fadila@utm.my
}

\begin{abstract}
The rapid development of science and technology requires universities to prepare competent human resources in their fields, one of which is the ability in teaching practice in schools. To improve the students' ability in teaching practice in both Indonesia and overseas schools, it requires a strategic effort, such as exchange student program. Therefore, Universitas PGRI Semarang conducts MOU with Universiti Teknologi Malaysia and Institut Pendidikan Guru Malaysia. Through this program, the students are expected to be able to adapt the character learning and become a professional teacher in the future.

Factors influencing the success of the students in joining the exchange program can be seen from the internal and external aspects. Therefore the purpose of this study is to determine what factors influence the success of teacher students of Universitas PGRI Semarang in Malaysia. The population of all students who joined the international PPL program in Malaysia is 18 students with random sampling for students teaching in grade 4 and 5 . The data were obtained from questionnaire and interview.

Based on the questionnaire, it is found that $95 \%$ of Universitas PGRI Semarang students are very pleased to join the International PPL program in Malaysia, as the cultural environment similar to the Indonesian nation give the easier adaptation process. Based on the interview with the students, the benefits of this program are as follows: 1) $90 \%$ of students claim to gain new life and social experiences; 2) $87 \%$ of students get additional knowledge about education in Malaysia; 3) 92\% of students get strong fraternity from other apprentice students of other state / private universities, and 4) only $30 \%$ of students are constrained by the language difficulties, $30 \%$ of students have difficulties in learning time, and $20 \%$ of students have difficulties in funding.
\end{abstract}

Keywords: factors of succesful teaching practice, international PPL program.

\section{Introduction}

The rapid development of science and technology requires universities to prepare competent human resources in their field, one of which is the ability of students in teaching in school. In improving students 'skills in teaching both campuses in Indonesia and Malaysia, strategic efforts are needed, one of which is the student exchange program for teaching in other countries. Therefore Universitas PGRI Semarang is moving quickly in improving students ability in teaching by conducting MOU with Universiti Teknologi Malaysia and the Institute Pendidikan Guru Malaysia. Through this program, it is expected that students are able to study culture in Indonesia and Malaysia that can make them able to adapt to the student characters in both countries. This is a very important provision for students so as to become professional teachers in the future. Universitas PGRI Semarang students have been provided with four basic skills including professional skills, pedagogical skills, social skills and personality skills are interrelated so as to make students confident in running the process of teachinglearning in Malaysia

The international PPL program is aimed at giving the students of the faculty of education the opportunity to take practice courses at other universities that overshadow the same purpose of teaching practice in practical schools. In a practice school under a foreign college that has established a cooperation agreement, students participating in the interantional PPL program will learn to apply student-centered educational strategies as subjects of learning. In addition, the implementation of this teaching practice will also provide a motivational development in the teaching profession for students of the program (1). Cooperation between colleges and other institutions will provide maximum benefit for the advancement of joint education if supported by the interest, involvement, and commitment to cooperate based on the international approach in terms of professional development in the field of teaching, research and service (2). Educational co-operation will provide opportunities to improve the quality of education, expand access and strengthen networks among high-ranking university graduates who have participated in internships exchange programs will have intercultural competence, enhance personal, social and intellectual development (3).

Globalization is the process of interaction and integration between individuals, corporations, and governments from different countries and regions (4). The process of globalization was initially perceived as a purely commercial and business-based activity in the international sphere. Furthermore, the process of globalization also has an impact on the environment, culture, political system, economic development and also the welfare of mankind in this world. In the same context, we live in a world of globalization where internationalization in the education sector refers to a comprehensive process of institutional transformation aimed at inte- 
grating intercultural and international dimensions in a mission and substantive function of institutional institutions. Therefore, cooperation among university institutions is built as the foundation and the essence to achieve internationalization of education in the form of student internship exchange program especially for students of science education faculty (5).

An internship exchange program should be able to provide a unique and rare opportunity for students to be able to gain teaching experience at foreign practice schools, combined with the opportunity to live in a foreign country. The main reason for the success of the apprenticeship exchange program in the faculty of education is based on the well-established network of universities already experienced in education and teaching and also qualified lecturers who are ready to dedicate their energy and mind to apprenticeship exchange program. Regular visits are scheduled to maintain monitoring or monitoring of student performance at the practice school where apprenticeship internship programs are discussed and to discuss any possible problems they may encounter there. Students who participate in the program will feel that the experience in this program is fantastic and it can provide an opportunity to develop future academies and careers as well as capabilities that can broaden the idea of cultural and personal ideas (6).

This study examines the benefits of international PPL program between Universitas PGRI Semarang and University Teknologi Malaysia which is expected to build relationships, beliefs, and attitudes towards the host country so as to produce lasting symmetrical power. The cooperation that has been established between Universitas PGRI Semarang and Universiti Teknologi Malaysia in international PPL program for the last 2 years aims to improve the quality of different human resources than those who spend time in their home universities. So they will have potentially better prospects in the job market as well as in the university environment. The urgency of this international PPL program cooperation is to establish cooperation in the field of research and publication on the international level. This cooperation will continue on a continuous basis and conducted research to analyze the usefulness of international PPL program between students of Universitas PGRI Semarang and Universiti Teknologi Malaysia.

\section{Literature Review}

The factors influencing the success of the students in joining the inter-state teaching exchange program can be seen from the internal and external aspects of the students. Therefore the purpose of this study is to determine what factors influence the success of Universitas PGRI Semarang students' teaching performance in Malaysia, the population of all students of international PPL program in Malaysia is 18 students with random sampling and they teach in 4th and 5th grade or it is as the high school level in Indonesia. The data are obtained from questionnaire and interview.

\subsection{University Student Exchange Program}

The student exchange program will provide many opportunities as well as benefits for the students and the college itself. The first is the benefits of education. One of the reasons why students choose to participate in student exchange programs is the learning opportunities provided by the program. In addition to simple things such as the acquisition of credit numbers in the courses of basic subjects, students will also gain experience of various acceptance of various ways of learning. They will learn to analyze the things around them with constructive actions and learn how to find solutions to problems in their own way. Students who take the student exchange program are also able to learn a language other than a new one empirically and will have experience with methods, systems, and learning techniques in other countries. They will also gain access to some courses that do not yet exist in their home country.

The next benefits of student exchange are personal benefits. In addition to the additional benefits of student education, those participating in student exchange programs will also benefit enormously in the personal level. With the opportunity to develop themselves in new and unfamiliar places, students will have the opportunity to develop their self-awareness as well as their selfesteem in an act that can not be imitated by others who do not have the same opportunity. They will learn to develop the ability to cope with social challenges outside their zone of safety and train themselves to face all kinds of problems in reality. In addition, students participating in student exchange programs must learn how to live and together with a variety of home life at a homestay where they will learn how to express their opinions on what is the biggest problem in life in the country where they study (7)

The next benefit is the long-term benefits. Although student exchange programs only last for one semester or one academic year, students enrolling in student exchange programs will learn the various skills that will stick to themselves throughout their lives. Once a student who has taken an exchange student program graduates from college and starts looking for a job, there is no doubt that many companies will be more interested in students who have been exploring in some countries overseas or in the world. Changes in social changes that occur in student exchange programs are easy to recognize, that is, they are more flexible in a variety of foreign situations, such as adaptation of new jobs, training training, or public speaking (8).

There are many benefits to be gained and perceived and beneficial in all situations and conditions as graduate students begin to look for work, where the opportunities they gain in participating student exchange programs bring a great deal to those sought by various companies. The graduates will have high communication skills, teamwork, and interpersonal skills. Graduate students who have participated in student exchange programs will also have the motivation, initiative, and also high enthusiasm. They will have the capacity to think critically and independently. In addition, they also have the ability of flexibility and adaptation, the spirit of professionalism and confidence, and the ability of problem-solving, creativity, and excellent skills of IT(9).

\subsection{The Effective Teaching Program}

The general purpose of an apprenticeship program is to encourage attitudes, behaviors or skills in any way that positively impact the performance outcomes. Therefore, to find out whether the teaching apprentice has been running well, it is necessary to have evaluation activities implemented to identify what needs to be eliminated and what points to be developed (10). Supervisors are instrumental in the process of apprenticeship, where this apprentice program requires a systematic method that can be used to determine what makes student performance less than expected or vice versa. Therefore, it is important to consider the factors that affect the outcomes of this teaching internship program.

There are nine factors that need to be considered and applied so that it will be able to maximize the outcomes of this teaching internship program. The nine factors are the analysis of the need for apprenticeship teaching, teaching apprenticeship methods, apprenticeship funding, environment and internship facilities, the strengthening of the teaching internship program, the supportive organizational arrangements, the characteristics of the supervisor, the time allocation, and the characteristics of the apprentices (11). The teaching internship program should be designed in such a way that it is integrated into a broader institutional development program. Furthermore, there needs to be a comprehensive strategy that can be developed while also considering all the strengths and weaknesses of schools and colleges to be able to provide a framework for future analysis. The skills and knowledge of the students and lecturers should be determined and assessed before 
the apprenticeship program is conducted so that it reflects current job requirements and qualifications (12).

\subsection{The Development of Teaching Skills in Class}

The reform and opening up of society in the 21st century is exposing to the fierce, international competition in the aspect of education and many other aspects . As a result, development of the society obviously requires the talent with high quality. At the same time, there is also an urgent need of the continuous updating of knowledge and skills, and so the demand for lifelong education has become stronger (13). One way to fullfil the requires of high quality in education aspects is improving the teaching skills as early as possible for the prospective teachers as the teacher training students in the faculty of education.

Becoming a better teacher is something that all educators must pay attention to. Good teachers are effective classroom managers and communicators who can adapt to different learning styles and effectively have the ability to provide instruction in the classroom. Therefore, in the apprenticeship program it is important to emphasize how efforts can be made in improving classroom teaching so as to have a significant impact on the lives of students or students (14).

Internship students are trained to develop teaching skills in the classroom. There are three important aspects to consider in developing teaching skills in the classroom. The first is what the teacher does, then the difference in knowledge that teachers need to have in order to provide the best performance in teaching, and the last is the attitudes and support values adopted and applied by the teacher (15).

In this case, the apprentices need to understand, analyze, then apply that what the teacher does and the consequences in the classroom will show how far his teaching skills are. Knowledge and attitudes of teachers is a fundamental factor that shapes the actions of a teacher. To improve teaching skills is very important for a teacher to keep up to date on the development of science and competence. Furthermore, cooperation with other people, inside and outside the higher education environment in the form of an internship student exchange program cooperation is one way to develop teaching skills (16).

In addition, an internship program demonstrating teaching skills in an international class or in a national class with international standards in completing a project assignment provides an opportunity for learners to develop their potential and creativity to develop different teaching and learning alternatives at different universities.

\section{Methodology/Materials}

3.1. This type of qualitative research was conducted to describe the impact of internship exchange program and to redesign the cooperation internship program between Universitas PGRI Semarang and Universiti Teknologi Malaysia.

3.2. The method of this research is qualitative research (17). The data of the research are analyzed descriptively qualitative. Qualitative research methods aim to understand or interpret phenomena in the sense of meaning. Qualitative research can determine the initial question which can then be addressed in quantitative studies. Qualitative data analysis can be done using explicit, systematic, and reproductive methods. By using this method, it is expected to get a complete picture of the factors that affect the exchange program of apprenticeship students and redesign partnership program between University PGRI Semarang and Universiti Teknologi Malaysia. The data are obtained from interviews and questionnaire responses of students who teach in Malaysia for a period of 1 month.

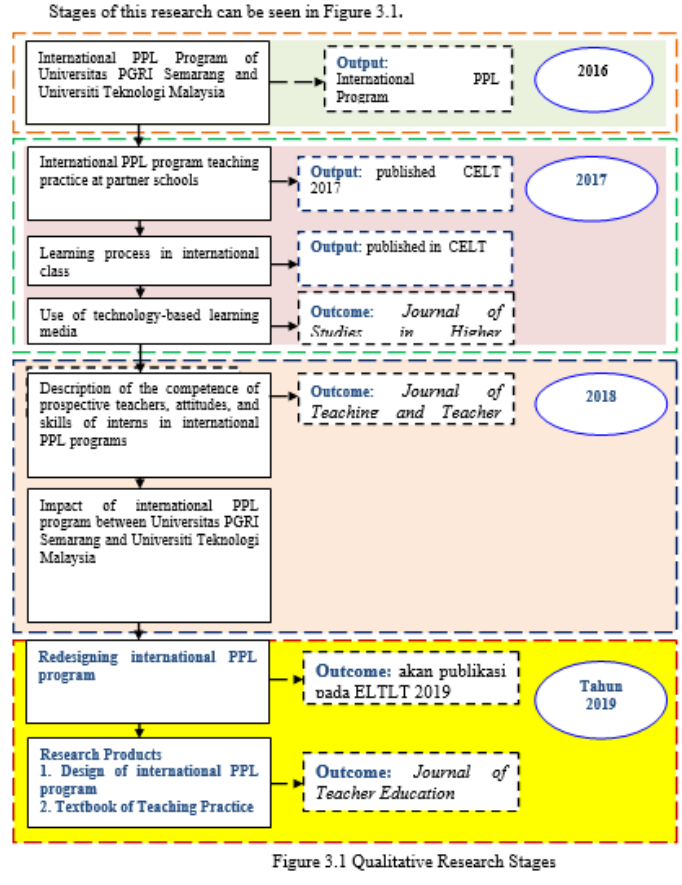

\subsection{Research Instrument}

The instruments are developed and designed based on research problems and research stages. Broadly speaking the instrument is divided into two namely; 1) instruments at each stage of the research to collect the necessary data. 2) assessment instruments to analyze the impact of international PPL programs.

At the preliminary study stage and the implementation of the study, it is developed the necessary instruments for field study, as listed in Table 3.1.

Table 3.1 Research Instrument at Introduction and implementation of the study Stage

\begin{tabular}{|c|c|c|c|c|}
\hline Aspects & Indicators & $\begin{array}{c}\text { Data } \\
\text { Sources }\end{array}$ & Instrument & Time \\
\hline $\begin{array}{l}\text { Profile of } \\
\text { student } \\
\text { skills in } \\
\text { teaching } \\
\text { practice }\end{array}$ & $\begin{array}{l}\text { Teaching } \\
\text { skills, } \\
\text { learning } \\
\text { media \& } \\
\text { laboratory } \\
\text { activities }\end{array}$ & $\begin{array}{l}\text { Lecturing } \\
\text { and } \\
\text { teaching } \\
\text { practice } \\
\text { process }\end{array}$ & $\begin{array}{l}\text { Observation } \\
\text { sheets, } \\
\text { interviews } \\
\text { and } \\
\text { questionnaire } \\
\text { s }\end{array}$ & $\begin{array}{l}\text { Preliminar } \\
\text { y studies }\end{array}$ \\
\hline $\begin{array}{l}\text { Attitudes } \\
\text { and views } \\
\text { of teachers } \\
\text { and stu- } \\
\text { dents to } \\
\text { internation- } \\
\text { al PPL } \\
\text { programs } \\
\text { between } \\
\text { universities }\end{array}$ & $\begin{array}{l}\text { Knowledge } \\
\text {, attitudes } \\
\text { and skills } \\
\text { of teachers, } \\
\text { univerisity } \\
\text { students, } \\
\text { and } \\
\text { students at } \\
\text { partner } \\
\text { schools }\end{array}$ & $\begin{array}{l}\text { Teachers \& } \\
\text { students at } \\
\text { school } \\
\text { practice }\end{array}$ & $\begin{array}{l}\text { Observation } \\
\text { sheets, } \\
\text { interviews } \\
\text { and } \\
\text { questionnaire } \\
\text { s }\end{array}$ & $\begin{array}{l}\text { Data } \\
\text { retrieval }\end{array}$ \\
\hline $\begin{array}{l}\text { The Effects } \\
\text { of } \\
\text { Internationa } \\
1 \text { PPL } \\
\text { Program }\end{array}$ & $\begin{array}{l}\text { Teaching } \\
\text { practice, } \\
\text { student } \\
\text { competence } \\
\text { in } \\
\text { internationa } \\
1 \text { class and } \\
\text { foreign } \\
\text { cultural } \\
\text { mastery }\end{array}$ & $\begin{array}{l}\text { Internationa } \\
1 \text { PPL } \\
\text { Program } \\
\text { process }\end{array}$ & $\begin{array}{l}\text { Observation } \\
\text { sheets, } \\
\text { interviews } \\
\text { and } \\
\text { questionnaire } \\
\text { s }\end{array}$ & $\begin{array}{l}\text { Data } \\
\text { retrieval }\end{array}$ \\
\hline
\end{tabular}

\section{Results and Findings}

Teaches plays an important role in educational sysem because of that the pedagogical program is stated as adequate and efficient if education is able to provide teachers that are highly experienced, 
well-knowledge and motivated for performing methodological issues in teaching education as good as possible. Moreover, some researches show that teacher evaluation has positive impact on teaching and learning processes are considered to be an important point in the educational system (18). Based on the statement above, it is very important for universities that have faculty of education to have an outstanding program that can improve the teacher training students that have the role as prospective teachers to have more knowledge, skills, and insight in teaching performance and education life skills that can improve their career as professional teachers in the future.

Prospective teachers will be able to develop their teaching performance if they have already set up, learned, and implemented the professional plans, satisfaction levels, demografic characteristics, perceptions and motivations before and during their teaching performance in classroom practice (19). Therefore it is necessary for the prospective teachers to understand, and to analyze what they need before and during the student exchange program that is international PPL program held and undergone in Malaysia. There are always pluses and minuses of an exchange program. Through the pluses and minuses, a program can be improved after it is evaluated (20). It is important for the students to have the skills of adaptation toward the academic cultures in the destinied country such as the medium of instruction, the academic calender, the education system, and the curriculum. The other important thing that can support the success of prospective teachers from Universitas PGRI Semarang to join and to involve themselves in the teaching activities as the program of international PPL program is taking a good attention on the budget. Having a good plan on the budget needed within the program really gives a great impact on the success of students' performance (21). Budget is important to be considered as it is important to make sure that the students will get the approapriate facilities related to the cost of living so that they will not find difficulties to pay the expenses of the meals, transportation, accomodation, or even the expenses needed to provide the teaching materials for teaching in the school practice.

Based on the questionnaire on table 4.1, the respondents' questionnaire data shows that 95\% of Universitas PGRI Semarang students are very pleased to be able to join the International PPL program in Malaysia, this is because the facilities and culture similar to the Indonesian nation so that it can facilitate the adaptation process in schools in Malaysia. Then, based on interviews with students, the data obtained from this program are as follows: 1) $90 \%$ of students claim to have new experiences because not all students of Universitas PGRI Semarang can join the same program 2) $87 \%$ of students get additional knowledge and education related knowledge in Malaysia 3) 92\% students gain a strong fraternity from the school and apprentice students from other private or state universities from Indonesia or other countries that are having the same student exchange program in Malaysia.

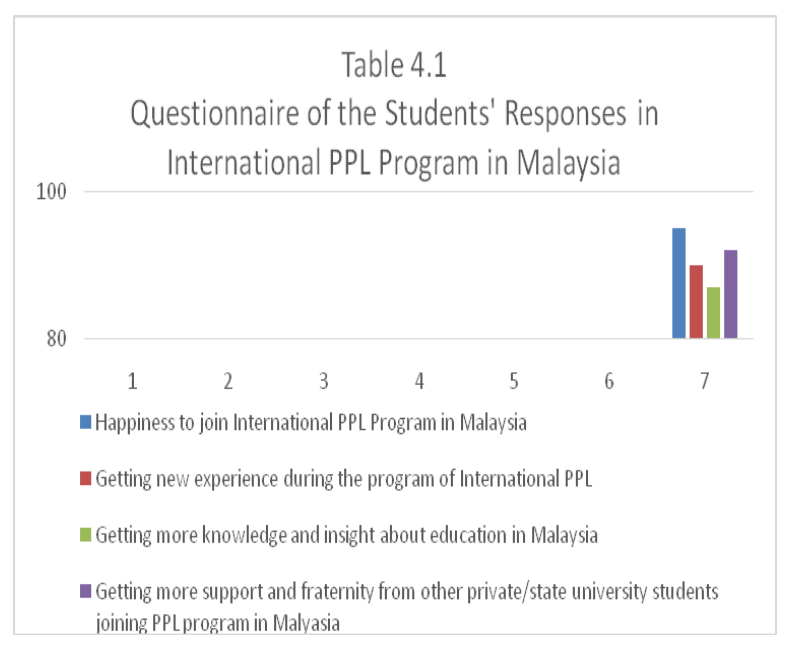

New environment is very promising to give additional knowledge and insight for teacher training students of Universitas in which they are still young and still have lack of experience in teaching. Environtment in the new place that is the university in overseas country will give opportunities to develop the success of teaching performance such as classroom size and group size, instruction time utilised wisely in lecture, practice, discussion and conclusion, instruction method according to established students' learning styles, and repetition of parts of the instruction for clarification (22). Thus, there are so many benefits that Universitas PGRI Semarang students can take from the international PPL program, they will get lots of experience through the classroom environment they got during joining the program in Malaysia. They can get the new academic cultures that are different from the home university and they will also learn how to do the adaptation of the new academic cultures that by doing so will enhance their soft skills very useful to improve their teaching performance.

Furthermore, based on the questionnaire on table 4.2, there are 3 obstacles faced by students in the learning process in Malaysia that is 1) $30 \%$ of students are constrained because English and Malay language is quite difficult to learn, the 2) as much as $35 \%$ of students find difficulty in adapting to the learning time, because time or calendar academic in Indonesia is different from those in Malaysia, so that it makes students can not do the maximum teaching performance in school, 3) as much as $20 \%$ of students find difficulties in funding because there is no funding supported by the university.

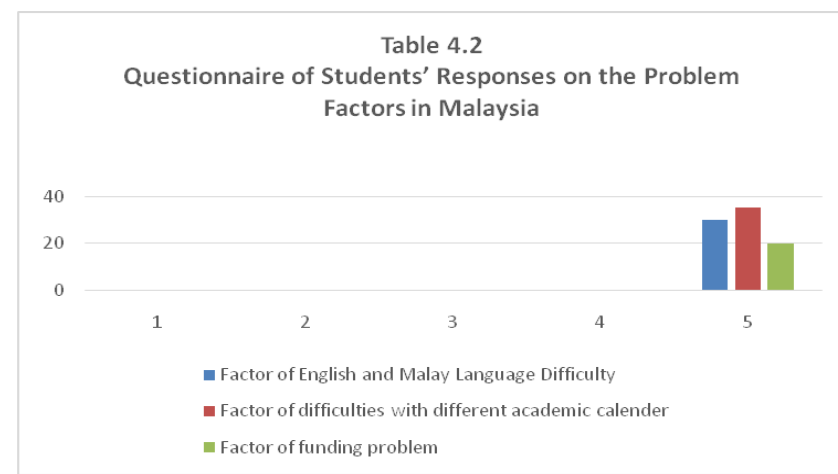

Education is especially designed to prepare skillful manpower that is ready to face and improve their capability for economic growth and development. Besides that, education is also designed to encourage learners to be practical and creative so as they will be able to have professional development and self-relient. Through education, it is hoped hat learners will be able to have skills and knowledge valuable for the society after their graduation from higher education (23). Concerning to that statement, it is very important for higher education to pay attention on the graduate outcome as well as the success of each of their program. Universities as higher education should be able to do the evaluation of each of their attention and improve the pluses and find out the solution of their minuses. From Table 4.2 about students' responses on the problem factors they faced during the international PPL program as the student exchange program with Universiti Teknologi Malaysia, Universitas PGRI Semarang must be able to find the solution of the problems faced by the students when undergoing the program in Malaysia.

The solution of the problems toward the language difficulties found by the students, what Universitas PGRI can do is by providing the selected students who will join the internaional PPL program a short English course and a short Malay course so that it will minimize the students' difficulties in English and Malay language. For the second problem related to the academic calendar of Malaysian schools that are different from those in Indonesia, the solution is there should be socialization of the academic calender in Malaysia during the microteaching program before they go for the international PPL program. The last problem if it is 
related to the funding problem, there should be saving account program for all of the students in Universitas PGRI Semarang. Through that saving account, there will be more readiness for the students to join some university programs that require lots of money beside the institution itself should be able to provide budget for that program that is especially given for the potential students that is in the form of scholarship.

Motivation given by the guidance teachers in the school practice really gives one of the great contributions the success of the students' teaching performance (24). The teacher's teaching of moral and model given to the students is very important aspect that gives the strength to the study of life skills that is very important for their future work and career (6). The results of interviews with students who teach in schools in Malaysia show that every learning, teachers should apply at least one of the moral values. For example, hygiene, teachers must ensure early or at the end of the learning so that students should not leave the garbage in class. Then in addition to supervisors, students are also guided by Science teachers in the vocational school. Then in learning the teacher is obliged to use the time as effectively as possible in the learning activities. Then it is suggested in every learning, for the teacher to give praise to the brave student in expressing their opinion. In addition, teachers need to improve communication activities between students and students and between students and teachers.

The best teaching performance will be reached if the prospective teachers are able to learn how to implement the mixed method of student-center ed together with teacher-centered that they can learn from the observation of their guidance teacher's teaching activities in the classroom practice (25). Therefore, it is important to have the educational planning and previous readiness so that the success of teaching performance can be reached maximally. It is important for the prospective teachers to get as many knowledge as possible during their observation class. The influence of environmental and cultural factors shapes the students' performance academically (11). The help of the guidance teachers in the school practice in Malaysia really gives and develops Universitas PGRI Semarang students to develop their teaching performance in class. The majority of teachers in Malaysia suggest in terms of teaching, a teacher should understand both cultural character and school culture so that teacher training students as prospective teachers will have better understanding on how to behave as the real educator and as professional teacher who knows better on how to educate their students. Besides that, guidance teachers in Malaysia also give insight to the teacher training students from Universitas PGRI Semarang on how to build discipline to students while at the same time they are supposed not to judge students in the sense of saying students as wrong or other negative things. They also give reinforcement to the prospective students of Universitas PGRI Semarang to master the material by not always seeing the book while teaching but they must be wellprepared before giving their teaching performance. The next reinforcement given by the teachers from Malaysia is that prospective teachers should be able to make students active or use methods that can make students always do activities in the classroom, either asking or answering questions. And the last enlightenment given by the teachers in the school practise in malaysia is that teacher should always receive the strength and the weaknesses of students by always seeing the psychological condition of students and always face to face with students rather than giving back to the students while doing learning activities Some of these things need to be done so that the learning objectives can be achieved well. Any problems in the learning world can be solved by the teacher if the teacher can accept the advice of the people around him and be able to adapt to the development of technology. it means that teachers' perspective towards the success of teaching learning is so important (24). It can improve students' motivation whom they are at the same time prospective teachers that should improve their teaching performance.
The roles of guidance teachers in the school practice and the role of the faculty of education in the home country and the overseas country in which they have the collaboration wih are very important in giving the support for the perspective teachers on how to increase the students' motivation, help them feel confident in solving problems, teach them to plan their learning acivities, help them to carry out self-assessment at the end of each lesson, encourage them to motivate themselves for the future work, and give them feedback and inform them about their individual learning (26). Universitas PGRI Semarang students from faculty of education have learned many things from the guidance teachers in the school practice and the lecturers and the academic personels in Universiti Teknologi Malaysia who have helped them a lot to improve their teaching performance and learn many things related to teaching materials and activities and also teaching skills and methods.

Exchange student program is very important program that can be used as a marketing tool to improve the better quality for a university. The best university is those that are able to establish outstanding program which can improve the quality of the graduate students in which one of them is an student exchange program (27). Because of that, Univesitas PGRI Semarang takes great consideration the importance of having collaboration with Universiti Teknologi Malaysia in the form of International PPL program that is able to give beneficial effects on both the students and the institution so as to improve the high quality of higher education in Indonesia. Thus, it is crucial to pay attention on the factors that lead the succes of students' teaching performance and their social life during undergoing their international PPL program in Malaysia.

\section{Conclusion}

To conclude, there are some factors that influence the success of teaching of teacher training program in the school practice in the student exchange program such as international PPL program held in the collaboraion with the overseas university. Efficiency in the teaching and learning activity can be achieved only by acquiring and operating with educational strategies focusing on the intelectual work skills as the strategies in the teaching activiy will lead to learning progress seen in the students' results (28).

Beside that, the other factors needed to support the success of the students' teaching experience in overseas country are the facilities and the social culture that can be adapted by the students so that they will be happy and motivated to have their teaching practice there (29). the next factor is the opportunity that the students got in joining the international PPL program make them motivated to do their best teaching practice in the school partner in the other country. The next factor that leads to the success of the students' teaching performance is the additional educational insight and knowledge they got from their guidance teachers, friends, students in the school practice.

The strong fraternity from schools and apprentices from other state/private university students also give additional factors that are able to give insight and enlightment for the prospective teachers to improve their best teaching performance.

The next factors that need to be concerned are the students' capability of the language and the academic calender in the country where they have the international PPL program. It is important that they have the minimum knowledge of the language being used there and have the adjustment of the acadamec calender and make the preparation of the schedule earlier to help them in following the academic activities in the school practice. And the last factor is the enough funding for the exchange students who join the international PPL program so that they have no problem with the cost of living they face in the overseas country.

To conclude, there are some factors that influence the success of teaching of teacher training program in the school practice in the 
student exchange program such as international PPL program held in the collaboraion with the overseas university. Efficiency in the teaching and learning activity can be achieved only by acquiring and operating with educational strategies focusing on the intelectual work skills as the strategies in the teaching activiy will lead to learning progress seen in the students' results (29).

Beside that, the other factors needed to support the success of the students' teaching experience in overseas country are the facilities and the social culture that can be adapted by the students so that they will be happy and motivated to have their teaching practice there. the next factor is the opportunity that the students got in joining the international PPL program make them motivated to do their best teaching practice in the school partner in the other country. The next factor that leads to the success of the students' teaching performance is the additional educational insight and knowledge they got from their guidance teachers, friends, students in the school practice.

The strong fraternity from schools and apprentices from other state/private university students also give additional factors that are able to give insight and enlightment for the prospective teachers to improve their best teaching performance.

The next factors that need to be concerned are the students' capability of the language and the academic calender in the country where they have the international PPL program. It is important that they have the minimum knowledge of the language being used there and have the adjustment of the acadamec calender and make the preparation of the schedule earlier to help them in following the academic activities in the school practice. And the last factor is the enough funding for the exchange students who join the international PPL program so that they have no problem with the cost of living they face in the overseas country.

The success of education policy does depend on the educators as the doer of the education implementation in society (30). Teachers' attitudes towards the integration is very important toward the success of education implementation. Because of that, Universitas PGRI Semarang students as propective teachers need to learn the importantce of integration in education implementation so that they can improve their teaching performance and how to be successful in teaching activities.

Lifelong and continuing education are widely admitted as crucial to enhance the competiveness of the economical strenght and improve the quality of life for all people in the world (31). One of the way to improve the quality of higher education and the quality of the student graduate is through student exchange program where it will give experiences both the university and its students to get more knowledge, more practical education that is different from the home university. Because of that, it is very important for the faculty of education students to have the experience of joining the international PPL program so that they will get the experience of teaching skills not only in the home university but also in the other university in the other country.

\section{Acknowledgement:}

This research work is supported by the Project joint research between Universitas PGRI Semarang dan Universiti Teknologi Malaysia

\section{References}

[1] Buchanan J. Quality teaching: means for its enhancement? Aust Univ Rev. 2011;53(1):66-72.

[2] Ehrman C. On using benefit segmentation for a service industry: A study on college career counseling services. J Am Acad Bus. 2006;8(2):179-85.

[3] Helal A Al. Expensive Private Higher Education in Bangladesh Who Can Afford ? 2012;2(2):1-19.

[4] Hennig-Thurau T, Gwinner KP, Walsh G, Gremler DD. Electronic word-of-mouth via consumer-opinion platforms: What motivates consumers to articulate themselves on the Internet? J Interact Mark. 2004;18(1):38-52.

[5] Bailey AR, Chow CW, Haddad KM. Continuous Improvement in Business Education: Insights From the For-Profit Sector and Business School Deans. J Educ Bus. 1999;

[6] Bertolin JCG. The quasi-markets in higher education: from the improbable perfectly competitive markets to the unavoidable State regulation. Educ Pesqui. 2011;

[7] Hill C. International business: Competing in the global market place. Strateg Dir. 2008;1-16.

[8] Kohont A, Bergoč JN. On the way into the Bologna reform - a consideration of the quality and the role of human resource management in higher education system. Qual High Educ. 2010;7:12-36.

[9] Lizzio A, Wilson K, Simons R. University students' perceptions of the learning environment and academic outcomes: Implications for theory and practice. Stud High Educ. 2002;27(1):27-52.

[10] Walker P. What Do Students Think They (Should) Learn at College? Student Perceptions of Essential Learning Outcomes. J Scholarsh Teach Learn. 2008;

[11] Longanecker D a., Blanco CD. Public policy implications of changing student attendance patterns. New Dir High Educ. 2003;(121):51-68

[12] Wilkinson R, Yussof I. Public and private provision of higher education in Malaysia: A comparative analysis. High Educ. 2005;

[13] Woodhouse D. Quality Assurance in Higher Education: the next 25 years. Qual High Educ. 1998;

[14] Umemiya N. Regional quality assurance activity in higher education in Southeast Asia: Its characteristics and driving forces. Qual High Educ. 2008;14(3):277-90.

[15] Ginns P, Prosser M, Barrie S. Students' perceptions of teaching quality in higher education: The perspective of currently enrolled students. Stud High Educ. 2007;32(5):603-15.

[16] Fish S. First, kill all the administrators. Chron High Educ. 2003;2020.

[17] Marshall C, Rossman G. Designing qualitative research. Designing Qualitative Research (3rd edition). 1999.

[18] Sarpkaya R. Factors affecting individual education demand at the entrance to university: Adnan Menderes University sample. Kuram ve Uygulamada Egit Bilim. 2010;

[19] Brennan J, Teichler U. The future of higher education and of higher education research. High Educ. 2008;56(3):259-64.

[20] Rahman A, Uddin S. Statistical Analysis of Different Socio Economic Factors Affecting Education of N-W . F . P ( Pakistan ). J Appl Quant Methods. 2009;4(1):88-94.

[21] Bay A. Balancing Theory and Practice. 1999;9.

[22] Kotler P, Armstrong G. Principles of Marketing. World Wide Web Internet And Web Information Systems. 2010.

[23] Nadiri H, Kandampully J, Hussain K. Students' perceptions of service quality in higher education. Total Qual Manag Bus Excell. 2009;

[24] Arnon S, Reichel N. Who is the ideal teacher? Am I? Similarity and difference in perception of students of education regarding the qualities of a good teacher and of their own qualities as teachers. Teachers and Teaching: Theory and Practice. 2007.

[25] Briukhanov VM, Kiselev VI, Timchenko NS, Vdovin VM. Monitoring the Opinions of Parents of College Students as a Component of the Institution's In-House Education Quality Management System. Russ Educ Soc. 2010;52(5):79-88.

[26] Monem M, Baniamin HM. Higher Education in Bangladesh: Status, Issues and Prospects. Pakistan J Soc Sci. 2010;

[27] Akareem HS, Hossain SS. Perception of education quality in private universities of Bangladesh: A study from students' perspective. J Mark High Educ. 2012;

[28] Koslowski FA. Quality and assessment in context: A brief review. Qual Assur Educ. 2006;14(3):277-88.

[29] Ingvarson L, Beavis A, Kleinhenz E. Factors affecting the impact of teacher education programmes on teacher preparedness: Implications for accreditation policy. Eur J Teach Educ. 2007;

[30] Garza Mitchell RL. Approaching common ground: Defining quality in online education. New Dir Community Coll. 2010;

[31] Ashraf MA, Ibrahim Y, Joarder MHR. Quality Education Management At Private Universities in Bangladesh: an Exploratory Study. 2009;24:17-32. 